\title{
The Efficiency of Internal Marketing Dimensions to Achieve the Organizational Commitment in Private Universities of Kurdistan Region
}

\author{
Thabit H. Thabit ${ }^{1}$ Saif Q. Younus ${ }^{2}$ \\ ${ }^{1}$ Department of Computer Engineering and Information, College of Electronics Engineering, University of Nineveh, Mosul, Iraq \\ ${ }^{2}$ Department of Business Administration, College of Financial and Administrative Sciences, Knowledge University, Kurdistan Region, Iraq
}

\begin{abstract}
The current paper attempts to study the effectiveness of internal marketing (IM) dimensions as an effective internal tool for the economic unit to enhance the organizational commitment (OC) in the private universities of Kurdistan Region. The importance of the research can be stemmed from the important role of IM in the economic unit, which can increase the activity of economic unit and achieve the OC in private universities of Kurdistan Region. So, the applying of IM in the economic unit effectively can help to strengthen the loyalty of the employees and help economic units to keep their employees. The researchers concluded that there is a good level of agreement for the employees of private universities in Kurdistan Region of Iraq about the activities of IM in the study sample and their role to enhance OC. The researchers recommended making more efforts for meeting the material and moral needs of the employees and gaining their satisfaction to ensure their continued work and keep them from thinking about moving to other economic units.
\end{abstract}

KEY WORDS: Efficiency, Internal Marketing, Kurdistan Region, Organizational Commitment, Private University

\section{INTRODUCTION}

This The term of IM is a modern concept in marketing appeared at the end of 20th century in order to simulate the traditional marketing and pull the relationship between the economic unit and customers on the relationship between the economic unit and employees.

So, as economic units try to provide the best to their customers, they are trying to create an active relation with their staff, too.

IM was created to give an active role in economic units and to achieve success. Service economic units are

Koya University Journal of Humanities and Social Sciences (KUJHSS)

Volume 2, Issue 2, 2019.

Received 13 April 2019; Accepted 05 August 2019

Regular research paper: Published 16 January 2020

Corresponding author's e-mail: thabit.thabit@uoninevah.edu.iq Copyright (C2019 Thabit H. Thabit, Saif Q. Younus. This is an open access article distributed under the Creative Commons Attribution License. considered one of the most affected economic units in this term for their dependence on the human resource. Therefore, the performance of the employees in these economic units is the basis of their success. Thus, making marketing connected through internal channels within economic units (Hadj Aissa and Thabit, 2019).

In effect, it is the function of the economic unit to select, train, motivate and satisfy employees' material and moral needs and positively influence their commitment to economic units.

\section{RESEARCH}

\subsection{Methodology}

\section{Research Problem:}

The activating of IM is expected to be of benefit for achieving the OC. Thus, the problem that the current research addresses can be identified by posing the following questions:

1. What are the main dimensions of IM which achieve the OC? 
2. Can the implementation of IM dimensions contribute to achieve the OC in private university of Kurdistan Region?

\section{Research Objectives:}

The research attempts to achieve the following objectives:

1. Explaining the IM concept and the IM main dimensions and discussing IM impact on enhancing $\mathrm{OC}$ in economic units.

2. Clarifying the $\mathrm{OC}$ concept and its main dimensions within the economic unit.

\section{Research Importance:}

The researchers summarized the importance of the research as a study to review an internal tool which can be used in economic unit as an active competitive advantage of marketing, which can enhance the activity of the economic unit and achieve the $\mathrm{OC}$ in private universities of Kurdistan Region. So, the application of IM in the economic unit effectively can help to strengthen the loyalty of the employees and help economic units to keep their employees.

\section{Research Hypotheses:}

The research was set according to the following hypotheses:

$\mathbf{H}_{\mathbf{1}}$ : There is a statistically significant relationship between recruitment policy and the $\mathrm{OC}$

H2: There is a statistically significant relationship between organizational and administrative support and the OC.

H3: There is a statistically significant relationship between types of incentives and the OC

H4: There is a statistically significant relationship between training and development and the OC

H5: There is a statistically significant relationship between staff retention and the $\mathrm{OC}$

\section{THE THEORETICAL FRAMEWORK OF IM}

\subsection{The Definition of IM:}

IM can be defined as "selecting, hiring, practicing, motivating, encouraging, recompense, and supplying devices and technical facilities in order to deliver the required goodness of the offered service" (Kotler and Keller, 2006), while (Dunmore) defined it as "the philosophy and marketing practices of individuals who serve customers so that the most efficient individuals are hired and retained" (Dunmore, 2002). (Iqbal et al., 2012) has defined IM as a method to select and motivate the competent staff while retaining them provided that their skills and abilities are compatible with the nature of the work they do and satisfy their needs.
So, the term of IM doesn't have a uniform definition, where many researchers have provided definitions according to their perspective. As shown in Table (1), many definitions of IM explained according to scholars' opinions.

TABLE 1

The Main Definitions of IM

\begin{tabular}{|c|c|}
\hline The Definition & The Authors \\
\hline $\begin{array}{c}\text { Attracting and retaining good employees in } \\
\text { order to get the best performance from them }\end{array}$ & Farzad, et al, 2008 \\
\hline $\begin{array}{c}\text { Attracting, developing, motivating and retaining } \\
\text { qualified employees through work products to } \\
\text { satisfy their needs. }\end{array}$ & Al-Nasrawi et al., 2018 \\
\hline $\begin{array}{c}\text { Employees in IM are considered to be products, } \\
\text { activities, functions and internal management } \\
\text { concepts that are very important to attract and } \\
\text { satisfy customers }\end{array}$ & Chang \& Chang, 2009 \\
\hline $\begin{array}{c}\text { Training and motivating employees to serve } \\
\text { customers in the best possible way }\end{array}$ & Kotler and Keller, 2006 \\
\hline
\end{tabular}

So, IM can be defined as "an economic unit activities that keep and maintain its good employees to provide good services to clients".

\section{The Dimensions of IM:}

IM includes many dimensions related to human resource that focus on employee as it is one of the components of marketing mix in the economic units, which aim to pay attention to workers in the front and back lines and to be considered internal customers (Thabit and Raewf, 2018), these dimensions can be as follows (Hoffman and Bateson, 2010), (Zaman et al., 2012), (Alves et al., 2015):

1. Recruitment Policy: The recruitment policy, which includes polarization, selection and recruitment, can be consssidered the main dimension of IM, which is supposed to be completed efficiently and effectively. So, success in this achievement will be reflected in other activities of the economic unit.

2. Organizational and Administrative Support: The concept of organizational and administrative support stems from the theories of social exchange and benefits exchange. These theories have contributed to the explanation of the motivation behind attitudes and behaviours of working individuals towards management.

3. Staff Retention: economic units that hire good staff and make a great effort to train and develop them and provide them with the necessary support to ensure a high level of quality of internal service, these economic units must make greater efforts to maintain them.

4. Types of incentives: The incentives and privileges obtained by workers is one of the main dimensions of retention, as many workers leave work in some economic units for reasons related to the quality of those incentives, so economic units pursued at rising 
the productivity of their staff have to deal with the issue of incentives, whether incentives are individual or collective, material or moral.

5. Training and Development: Goodness of services that meet customers' expectations is the goal that all economic units must strive to achieve. The key to this process is to provide the necessary training programs for all employees. Training is one of the main tools that contribute to the development of individuals and their qualifications to do their jobs best.

\section{The Importance of IM:}

Economic units are interested in training employees, strengthening their skills and determining the forms of cooperation among them according to IM concept, which contributes solving internal relations problem in the economic unit (Thabit et al., 2016). Therefore, the importance of IM can be identified as follows (Ahmed et al., 2003):

1. IM contributes to providing a stimulating environment conducive to employee satisfaction.

2. IM is geared towards employees to achieve an acceptable level of job satisfaction.

3. IM engage to the integration and coordination of the economic unit's internal activities related to employees and their relationships.

4. IM contributes to apply a practical and inclusive strategy for the economic unit through which to achieve the long-term goals of employees.

\section{The Objectives of IM:}

The adopting an effective IM policy will achieve the following objectives (Awwad and Agti, 2011):

1. Dissemination and exchange of information among working groups who interact with marketing activities in order to make effective marketing decisions.

2. Activating incentives through which employees are encouraged and motivated to continuously improve performance.

3. Developing the capabilities and competencies of employees in industrial and service economic units.

4. Providing economic units with competent staff to perform administrative functions and communicate with the public.

5. The IM application of the economic unit helps to carry out internal promotion campaigns to encourage employees and activate their role in achieving the strategic objectives.

6. Creating an internal environment in which employees are aware of and enthusiastic about work, as one of the most important factors influencing this is the support of the senior management of the employees.
7. Maintaining highly skilled workers by providing them with all material and moral requirements.

\section{THE ORGANIZATIONAL COMMITMENT}

\subsection{Concept of OC}

OC is the staff's response to the economic unit' features to which they belong, and the staff's feeling of pertinence to the aims of the economic unit and the function they play to enhance the economic unit's aims and involvement to the economic unit's values (Bove and Johnson, 2006).

In another study, OC is seen as a kind of harmony between both aims of staff and economic unit. The employee who believes in the importance of the goals of the economic unit often has a positive sense of loyalty and a strong desire to stay at work (Cichy et al., 2009).

The OC is also seen as a multidimensional concept with different factors, outputs and implications for human resource management. This diversity is due to the fact that many staffs within the economic unit have their own goals and it is not necessary to engage employees in one goal.

\subsection{Dimensions of OC}

According to Meyer and Allen (1997), there are three dimensions of the $\mathrm{OC}$ as following (Boon and Arumugam, 2006):

\section{The Emotional Commitment:}

This kind of commitment is an emotional attachment and a strong sense of belonging, integration and participation in the economic unit. So, emotional commitment requires three conditions:

1. The formation of emotional attachment to the economic unit.

2. The strong feeling of pertinence to the economic unit.

3. The desire to retain organizational membership.

The employee will develop his or her emotional attachment to the economic unit when it recognizes its objectives and when the values of the employee match the values of the economic unit and the employee is able to understand and adopt the values and objectives of the economic unit. Thus, there is a psychological integration in the economic unit and the pride of belonging to it. So, employees with strong emotional commitment remain in their work.

\section{The Continued Commitment:}

Continued commitment requires the employee to recognize the magnitude of the disadvantages of leaving the economic unit. This is the key association of the employee with the economic unit and his/her decision to remain in it is an effort to maintain benefits. 
Others believe that this kind of commitment is just a deal, so employees calculate their investments in the economic unit based on what they have provided to the economic unit and what they will earn if they continue with it.

While others indicated that continued commitment could depend on the employee's perception of the work options available outside the economic unit.

\section{The Normative Commitment:}

The normative commitment reflects a sense of continuity within economic unit, this feeling is often reinforced by good support of the economic unit to its staff and allowing them to participate in addition to interact them positively not only in the implementation of the work but in contributing to the development of goals.

Staffs that have a high level of normative loyalty sense that they must stay with the economic unit and that many researchers such as David and Foray (2002), Allen and Meyer (1996), and Lewicka (2017) view normative commitment from an ethical perspective and call it a moral commitment.

The employee develops this type of commitment after the economic unit has invested in him/her. Employees feel that the economic unit has spent a lot of time and money in their development and training. They can meet this or compensate the economic unit by continuing to work for them.

\section{The connection between IM and OC:}

The IM concept's main direction is to assure that staff feels that the administration cares about them and works to meet the needs (Raewf and Thabit, 2015). Successful implementation of the concept it is translated through the positive attitudes of the workers towards their work including $\mathrm{OC}$, function participate and motivate work and job satisfaction (Ahmed and Rafiq, 2003).

There is a great relationship to a great relationship between IM and satisfaction consumer and IM and goodness of service provided (Budhwar et al., 2009).

Successful IM leads to increase staff's efficiency in achieving the required goals and providing all the necessary energies to implement them, and also contributes to reducing turnover of employees (Farrell et al., 2008).

\section{The Practical Part}

\subsection{Population and Study Sample}

The study population of this paper is the academics from 13 private universities in Kurdistan Region of Iraq which are shown in table (2). They are 1145 individuals.
TABLE 2

The Main Private University in KR of Iraq

\begin{tabular}{|c|c|c|c|}
\hline University & $\begin{array}{l}\text { Foundation } \\
\text { Year }\end{array}$ & City & $\begin{array}{c}\text { Total no. } \\
\text { of } \\
\text { academics }\end{array}$ \\
\hline Knowledge University & 2009 & Erbil & 57 \\
\hline Cihan University - Erbil & 2007 & Erbil & 320 \\
\hline Cihan University -Duhok & 2013 & Duhok & 84 \\
\hline Cihan University - Sulaimani & 2011 & Sulaimani & 50 \\
\hline $\begin{array}{c}\text { Tishk International University - } \\
\text { Erbil }\end{array}$ & 2008 & Erbil & 94 \\
\hline Tishk International - Sulaimani & 2014 & Sulaimani & 12 \\
\hline $\begin{array}{c}\text { Komar University of Science and } \\
\text { Technology }\end{array}$ & 2009 & Sulaimani & 34 \\
\hline American University in Iraq & 2007 & Sulaimani & 37 \\
\hline $\begin{array}{l}\text { American University in } \\
\text { Kurdistan }\end{array}$ & 2014 & Duhok & 24 \\
\hline Lebanese French University & 2007 & Erbil & 85 \\
\hline International University of Erbil & 2016 & Erbil & 18 \\
\hline Nawroz University & 2004 & Duhok & 170 \\
\hline $\begin{array}{l}\text { University of Human } \\
\text { Development }\end{array}$ & 2008 & Sulaimani & 160 \\
\hline
\end{tabular}

The researchers choose randomly their sample based on Yard equation; they calculated the sample of size by equation (1):

$$
\mathrm{n}=\frac{\mathrm{N}}{1+\mathrm{N}(\mathrm{e})} 2
$$

Where,

$\mathrm{n}=$ Sample size

$\mathrm{N}=$ Population $=1145$

$\mathrm{e}=$ error margin $=0.05$

So, the estimated size of research sample is (300).

The number of valid questionnaires for analyzing were (172) by (57.3\%) of the research sample and $(15.0 \%)$ of the research population.

\section{Study Tool}

The questionnaire was designed according to related studies and divided into five main parts by submitting 25 paragraphs as shown in tables (3-7).

TABLE 3

The Codes of $1^{\text {st }}$ Part of The Questionnaire

\begin{tabular}{cl}
\hline \hline Code & \multicolumn{1}{c}{ Paragraph } \\
\hline \hline $\mathrm{A}_{1}$ & $\begin{array}{l}\text { The management develops staff training programs } \\
\text { The management provides all the requirements of training } \\
\text { operations. } \\
\mathrm{A}_{2}\end{array}$ \\
$\mathrm{~A}_{3}$ & $\begin{array}{l}\text { The management measures the degree to which employees } \\
\text { benefit from training } \\
\mathrm{A}_{4}\end{array}$ \\
$\mathrm{~A}_{5}$ & $\begin{array}{l}\text { Training plans are developed based on pre-set goals } \\
\text { The management offers training courses on modern } \\
\text { subjects }\end{array}$ \\
\hline \hline & The Codes of 2st Part of The Questionnaire \\
\hline \hline $\mathrm{C}_{1}$ & $\begin{array}{l}\text { Training increases the efficiency of the employee to } \\
\text { accomplish the work }\end{array}$ \\
$\mathrm{B}_{1}$ & $\begin{array}{l}\text { Management allows staff to discuss problems and offer } \\
\text { solutions } \\
\mathrm{B}_{2}\end{array}$ \\
$\mathrm{~B}_{3}$ & $\begin{array}{l}\text { The employee has the freedom to act in order to meet the } \\
\text { customer's wishes } \\
\text { The management is keen to provide the necessary facilities } \\
\text { to perform the work } \\
\text { The employee has the powers to make decisions that } \\
\text { accelerate the response to customer needs }\end{array}$ \\
$\mathrm{B}_{4}$
\end{tabular}


TABLE 5

The Codes of 3rd Part of The Questionnaire

\begin{tabular}{|c|c|}
\hline Code & Paragraph \\
\hline $\mathrm{C}_{1}$ & $\begin{array}{l}\text { The management informs employees of the new services } \\
\text { and products that it intends to promote. }\end{array}$ \\
\hline $\mathrm{C}_{2}$ & $\begin{array}{l}\text { Management provides sufficient information on new } \\
\text { services and products. }\end{array}$ \\
\hline $\mathrm{C}_{3}$ & $\begin{array}{l}\text { There is nothing to prevent staff from communicating } \\
\text { among themselves and exchanging information and } \\
\text { experiences. }\end{array}$ \\
\hline $\mathrm{C}_{4}$ & $\begin{array}{l}\text { Employees are keen to spread their knowledge among their } \\
\text { team members. }\end{array}$ \\
\hline $\mathrm{C}_{5}$ & The management encourages teamwork. \\
\hline & $\begin{array}{c}\text { TABLE } 6 \\
\text { The Codes of } 4^{\text {th }} \text { Part of The Questionnaire }\end{array}$ \\
\hline Code & Paragraph \\
\hline$\overline{D_{1}}$ & Cooperation prevails among workers in the economic unit \\
\hline $\mathrm{D}_{2}$ & $\begin{array}{l}\text { Management is interested in exchanging ideas about working } \\
\text { with employees }\end{array}$ \\
\hline $\mathrm{D}_{3}$ & $\begin{array}{l}\text { Management provides a stimulating work environment for } \\
\text { employees }\end{array}$ \\
\hline $\mathrm{D}_{4}$ & $\begin{array}{l}\text { Management is keen to provide entertainment programs for } \\
\text { employees }\end{array}$ \\
\hline $\mathrm{D}_{5}$ & $\begin{array}{l}\text { The management is interested in strengthening social relations } \\
\text { in the workplace. }\end{array}$ \\
\hline & $\begin{array}{c}\text { TABLE } 7 \\
\text { The Codes of } 5^{\text {th }} \text { Part of The Questionnaire }\end{array}$ \\
\hline Code & Paragraph \\
\hline $\mathrm{E}_{1}$ & $\begin{array}{l}\text { The management supports creative opportunities for } \\
\text { employees. }\end{array}$ \\
\hline $\mathrm{E}_{2}$ & $\begin{array}{l}\text { The employee enjoys talking about his/her work with } \\
\text { friends out of business. }\end{array}$ \\
\hline $\mathrm{E}_{3}$ & $\begin{array}{l}\text { The employee likes to stay and continue his/her } \\
\text { current job. }\end{array}$ \\
\hline $\mathrm{E}_{4}$ & $\begin{array}{l}\text { The employee believes that leaving the work without } \\
\text { justification is immoral. }\end{array}$ \\
\hline $\mathrm{E}_{5}$ & $\begin{array}{l}\text { The employee believes that keeping one job for life is } \\
\text { better. }\end{array}$ \\
\hline
\end{tabular}

\subsection{The Statistical Methods Used for Data Analysing}

The researchers used Cronbach's Alpha test to define the questionnaire stability, and they used percentages, frequencies, standard deviations, arithmetic averages, and T-test to achieve the research aims and test the hypotheses by applying SPSS 22.0.

\section{1) Analysing of Questionnaire Stability}

The aim of using test of Cronbach's Alpha is evaluating the questionnaire's paragraphs consistency and accuracy degrees. Therefore, if the coefficient value of Cronbach's Alpha is $a \geq 0.6$ the questionnaire's paragraphs will be acceptable.

According to the results of SPSS, the value of $a=$ 0.688 , and the reliability value of $\alpha=0.712$ which means they are acceptable.

\section{2) The Test of Hypotheses}

Three statistical methods were used to test the hypotheses of the study (arithmetical average, standard deviation, and T-test) in order to determine the statistical decision for paragraphs.
The paragraphs of questionnaire were divided into five parts to test the sub-hypotheses of the study.

$\mathbf{H}_{\mathbf{1}}$ : There is a statistically significant relationship between recruitment policy and the OC.

\section{TABLE 8}

The Result of Analysing the $1^{\text {st }}$ Part of The Questionnaire

\begin{tabular}{cccccc}
\hline Code & A.A & S.D. & T-T. & Rank & Stat. D. \\
\hline \hline $\mathrm{A}_{1}$ & 3.69 & 0.857 & 6.54 & 2 & Sign. \\
$\mathrm{A}_{2}$ & 3.34 & 0.941 & 3.77 & 4 & Sign. \\
$\mathrm{A}_{3}$ & 3.44 & 0.914 & 5.47 & 3 & Sign. \\
$\mathrm{A}_{4}$ & 3.28 & 0.872 & 7.58 & 5 & Sign. \\
$\mathrm{A}_{5}$ & 4.01 & 0.844 & 7.41 & 1 & Sign. \\
& 3.552 & & & & \\
\hline \hline
\end{tabular}

As shown in Table (8), the results of analyzing the first part of the questionnaire are as following:

- All paragraphs of the questionnaire are clear and all are considered significant according to their arithmetic average and standard deviation values.

- $\mathrm{A}_{5}$ gets the highest rank comparing with the other according to the value of arithmetic average (A.A. $=4.01$ ) and the value of standard deviation (S.D. $=0.844)$, which implies the agreement of respondents about the considerable compatibility.

- The researchers accepted the hypothesis $\mathrm{H}_{1}$ due to the value of the arithmetic average of all paragraphs $\left(A_{1}-A_{5}\right)=(3.552)$ out of 5 .

$\mathbf{H}_{2}$ : There is a statistically significant relationship between organizational and administrative support and the OC.

TABLE 9

The Result of Analysing the 2nd Part of The Questionnaire

\begin{tabular}{cccccc}
\hline Code & A.A & S.D. & T-T. & Rank & Stat. D. \\
\hline \hline $\mathrm{B}_{1}$ & 4.21 & 0.875 & 8.12 & 1 & Sign. \\
$\mathrm{B}_{2}$ & 3.94 & 0.971 & 6.78 & 3 & Sign. \\
$\mathrm{B}_{3}$ & 3.99 & 0.854 & 6.54 & 2 & Sign. \\
$\mathrm{B}_{4}$ & 3.75 & 0.812 & 7.22 & 5 & Sign. \\
$\mathrm{B}_{5}$ & 3.91 & 0.894 & 7.44 & 4 & Sign. \\
& 3.960 & & & & \\
\hline \hline
\end{tabular}

As shown in Table (9), the results of analyzing the second part of the questionnaire are as following:

- All paragraphs of the questionnaire are clear and all are considered significant according to their arithmetic average and standard deviation values.

- $\mathrm{B}_{1}$ gets the highest rank comparing with other according to the value of arithmetic average (A.A. $=4.21$ ) and the value of standard deviation (S.D. $=0.875$ ), which implies the agreement of respondents about the considerable compatibility.

- The researchers accepted the hypothesis $\mathrm{H}_{2}$ due to the value of the arithmetic average of all paragraphs $\left(B_{1}-B_{5}\right)=(3.960)$ out of 5 .

$\mathbf{H}_{3}$ : There is a statistically significant relationship between staff retention and the OC. 
TABLE 10

The Result of Analysing the 3rd Part of the Questionnaire

\begin{tabular}{cccccc}
\hline \hline Code & A.A & S.D. & T-T. & Rank & Stat. D. \\
\hline \hline $\mathrm{C}_{1}$ & 3.75 & 0.887 & 5.21 & 3 & Sign. \\
$\mathrm{C}_{2}$ & 3.82 & 0.911 & 5.78 & 2 & Sign. \\
$\mathrm{C}_{3}$ & 2.04 & 2.041 & 1.87 & 5 & Not Sign. \\
$\mathrm{C}_{4}$ & 4.17 & 0.911 & 8.27 & 1 & Sign. \\
$\mathrm{C}_{5}$ & 3.65 & 0.845 & 6.57 & 4 & Sign. \\
& 3.486 & & & & \\
\hline \hline
\end{tabular}

As shown in Table (10), the results of analyzing the third part of the questionnaire are as following:

- The paragraphs $\left(\mathrm{C}_{1}, \mathrm{C}_{2}, \mathrm{C}_{4}\right.$, and $\left.\mathrm{C}_{5}\right)$ of the questionnaire are clear and are considered significant according to their arithmetic average and standard deviation values, but paragraph $\mathrm{C}_{3}$ gets ambiguity among the respondents because of its arithmetic average and standard deviation values therefore is considered not significant.

- $\mathrm{C}_{4}$ gets the highest rank comparing with the other according to the value of arithmetic average (A.A $=4.17)$ and the value of standard deviation $(S . D=0.911)$, which implies the agreement of respondents about the considerable compatibility.

- The researchers accepted the hypothesis $\mathrm{H}_{3}$ due to the value of the arithmetic average of all paragraphs $\left(C_{1}-C_{5}\right)=(3.486)$ out of 5 .

$\mathbf{H}_{4}$ : There is a statistically significant relationship between types of incentives and the OC.

TABLE 11

The Result of Analysing the $4^{\text {th }}$ Part of The Questionnaire

\begin{tabular}{cccccc}
\hline \hline Code & A.A & S.D. & T-T. & Rank & Stat. D. \\
\hline \hline $\mathrm{D}_{1}$ & 4.01 & 0.985 & 6.47 & 2 & Sign. \\
$\mathrm{D}_{2}$ & 4.05 & 0.899 & 7.04 & 1 & Sign. \\
$\mathrm{D}_{3}$ & 3.97 & 0.917 & 6.78 & 3 & Sign. \\
$\mathrm{D}_{4}$ & 3.84 & 0.844 & 6.72 & 4 & Sign. \\
$\mathrm{D}_{5}$ & 3.77 & 0.823 & 5.82 & 5 & Sign. \\
& 3.928 & & & & \\
\hline \hline
\end{tabular}

As shown in Table (11), the results of analyzing the fourth part of the questionnaire are as following:

- All paragraphs of the questionnaire are clear and all are considered significant according to their arithmetic average and standard deviation values.

- $\mathrm{D}_{2}$ gets the highest rank comparing with other according to the value of arithmetic average (A.A. $=4.05)$ and the value of standard deviation (S.D.=0.899), which implies the agreement of respondents about the considerable compatibility.

- The researchers accepted the hypothesis $\mathrm{H}_{4}$ due to the value of the arithmetic average of all paragraphs $\left(D_{1}-D_{5}\right)=(3.928)$ out of 5 .

H5: There is a statistically significant relationship between training and development and the OC.
TABLE 12

The Result of Analysing the $5^{\text {th }}$ Part of The Questionnaire

\begin{tabular}{cccccc} 
Code & A.A & S.D. & T-T. & Rank & Stat. D. \\
\hline \hline $\mathrm{E}_{1}$ & 3.95 & 0.853 & 7.01 & 1 & Sign. \\
$\mathrm{E}_{2}$ & 3.93 & 0.857 & 6.88 & 2 & Sign. \\
$\mathrm{E}_{3}$ & 3.91 & 0.961 & 6.92 & 3 & Sign. \\
$\mathrm{E}_{4}$ & 3.72 & 0.871 & 6.64 & 5 & Sign. \\
$\mathrm{E}_{5}$ & 3.88 & 0.911 & 5.12 & 4 & Sign. \\
& 3.878 & & & & \\
\hline \hline
\end{tabular}

Table (12) shows the following:

- All paragraphs of the questionnaire are clear and all are considered significant according to their arithmetic average and standard deviation values.

- $\mathrm{E}_{1}$ gets the highest rank comparing with other according to the value of arithmetic average (A.A.=3.95) and the value of standard deviation (S.D.=0.853), which implies the agreement of respondents about the considerable compatibility.

- The researchers accepted the hypothesis $\mathrm{H}_{5}$ due to the value of the arithmetic average of all paragraphs $\left(E_{1}-E_{5}\right)=(3.878)$ out of 5 .

\section{CONCLUSION AND RECOMMENDATIONS}

\subsection{Conclusion}

1. Results of this study found that there is a statistically significant relationship at the level of $\alpha \leq 0.05$ for the dimensions of IM (recruitment policy, organizational and administrative support, staff retention, types of incentives, and training and development) on the OC.

2. There is a variation in the degree of IM dimensions impact on the OC as follows:

a. Second dimension (organizational and administrative support) is more influential than the other dimensions at an agreement value equals (3.960).

b. Third dimension (staff retention) is less influential than the other dimensions at an agreement value equals (3.486).

3. The level of all IM dimensions agreements is good which equals (3.761).

4. The statistical analysis results of the show that there is a good level of agreement for the employees of private universities in Kurdistan Region of Iraq about the activities of IM in the study sample.

\subsection{Recommendations:}

1. Making more efforts to meet the material and moral needs of the employees and gain their satisfaction to ensure their continued work and keep them from thinking about moving to other economic units 
2. Organizing training and development courses for employees periodically and encourage creativity and cooperation.

3. Presenting marketing information to employees and share them in developing solutions to immediate and future problems.

4. Organizing conferences and symposia on the benefits of IM and the role of the employee in strengthen the economic unit's position in society.

5. Improving the system of material and moral rewards and enhancing the social responsibility of the economic unit towards employees.

\section{REFERENCES}

Ahmed, P.K., and Rafiq, M. (2003). Commentary Internal Marketing Issues and Challenges, European Journal of Marketing, 37(9), 1177- 1186.

Ahmed, P.K., Rafiq, M., and Saad, N. (2003). Internal Marketing and the Mediating Role of Organizational Competencies, European Journal of Marketing, 37(9), 1221-1241.

Al-Nasrawi, Hamed A., Al-Tameemi, Ali H., and Thabit, Thabit H. (2018). The Impact of Organizational Dogmatism in Reducing the Employees' Internal Marketing: A Case Study of General Company for Food Products in Baghdad, International Journal of Social Sciences \& Educational Studies, Ishik University, 5(1), 1627.

Alves, H., do Paço, A. and Roberto, C. (2015). Influence of Internal Marketing on Organizational Commitment-Evidence from Care Institutions for the Elderly, Market-Tržište, 27(2), 237-250.

Awwad, M.S., and Agti, D.A.M. (2011). The Impact of Internal Marketing on Commercial Banks' Market Orientation, International Journal of Bank Marketing, 29(4), 308-332.

Boon, O.K., and Arumugam, V. (2006). The Influence of Corporate Culture on Organizational Commitment: Case Study of Semiconductor Organizations in Malaysia, Sunway Academic Journal, 3(1), 99-115.

Bove, Liliana L., and Johnson, Lester W. (2006). Customer Loyalty to One Service Worker: Should It Be Discouraged? International Journal of Research in Marketing, 23(1), 79-91.

Budhwar, P.S., Varma, A., Malhotra, N., and Mukherjee, A. (2009). Insights into the Indian Call Centre Industry: Can Internal Marketing Help Tackle High Employee Turnover? Journal of Services Marketing, 23(5), 351-362.

Chang, C.S., and Chang, H.C. (2009). Perceptions of Internal Marketing and Organizational Commitment by Nurses. Journal of Advanced Nursing, 65(1), 92-100.
Cichy, R.F., Cha, J.M., and Kim, S.H. (2009). The Relationship between Organizational Commitment and Contextual Performance among Private Club Leaders. International Journal of Hospitality Management, 28, 53-62.

Dunmore, M. (2002). Inside-Out Marketing: How to Create an Internal Marketing Strategy, Kogan Page Business Books, London.

Farrell, M.A., Oczkowski, E., and Kharabsheh, R. (2008). Market Orientation, Learning Orientation and Organizational Performance in International

Joint Ventures, Asia Pacific Journal of Marketing and Logistics, 20(3), 289-308.

Farzad, A., Nahavandi, N., and Caruana, A. (2008). The Effect of Internal Marketing on OrganizationalCommitment in Iranian Banks, American Journal of Applied Sciences, 5(11), 1480-1486.

Hadj Aissa, Sid Ahmed, and Thabit, Thabit H. (2019). Modelling the Relevance between the Relationship Marketing and WOM Marketing through the Customer Satisfaction Case Study in Algeria Telecommunications Corporation, Tikrit Journal For Administration \& Economics Sciences, 15(45), 1-21.

Hoffman, K. D., and Bateson, J. E. (2010). Services Marketing: Concepts, Strategies, \& Cases: Concepts, Strategies, and Cases. Cengage Learning.

Iqbal, N., Ahmad, N., and Sheeraz, M. (2012). The Effect of Internal Marketing on Employee Retention in Pakistani Banks, International Journal of Academic Research in Business and Social Science, 2(8), 270-280.

Kotler, Philip, and Keller, Kevin L. (2006). Marketing Management, International Edition, Prentice Hall, New Jersey.

Raewf, Manaf Basil, and Thabit, Thabit Hassan, (2015). The Student's Satisfaction Influential Factors at Cihan University, International Journal Of Advanced Research in Engineering \& Management, $1(2), 63-72$.

Thabit, Thabit H., and Raewf, Manaf B. (2018). The Evaluation of Marketing Mix Elements: a Case Study, International Journal of Social Sciences \& Educational Studies, 4(4), 100-109.

Thabit, Thabit H., Hadj Aissa, Sid A., and Harjan, Sinan A. (2016). Using Fuzzy Logic to Evaluate the Relationship between Designing Training Program and Level of Creativity and Innovation, International Journal of Innovation and Scientific Research, 25(1), 121-129.

Zaman K., Javaid, N., Arshad, A., and Babi, S. (2012). Impact of Internal Marketing on Market Orientation and Business Performance, International Journal of Business and Social Science, 3(12), 76-87. 